\title{
Prevalance of Celiac Disease in Subjects With Diverticular Disease of the Colon
}

\section{Kolon Divertiküler Hastalığı Olan Hastalarda Çölyak Hastalığı Sıklığı}

\author{
Mesut Aydin $^{1^{*}}$, Serhat Ozer ${ }^{2}$, Yaren Dirik ${ }^{1}$, Elif Tugba Tuncel ${ }^{3}$, Ahmet Cumhur Dulger $^{4}$ \\ ${ }^{1}$ Van Yuzuncu Yil University, Medical Faculty, Department of Gastroenterology, Van \\ ${ }^{2}$ Private Defne Hospital, Department of Gastroenterology, Antakya \\ ${ }^{3}$ Manisa City Hospital, Department of Gastroenterology, Manisa \\ ${ }^{4}$ Giresun University Faculty of Medicine Department of Gastroenterology, Giresun
}

\begin{abstract}
Objective: Celiac disease is a small bowel malabsorption syndrome that is caused by hypersensitivity to wheat in subjects who have positive HLA haplotypes DQ2 and DQ8. Diverticular disease of the colon is saccular dilatations of colon, which is seen mostly in adults older than 40 . In this study, we tried to see whether celiac disease is protective for diverticular disease of the colon.

Material and Method: We identified 114 (57 female; the mean age $58 \pm 4.1$ years) patients with DDC during the 7 -month period from January to October 2018. Age-matched control group (100 subjects; 50 female; the mean age $59 \pm 3.4$ years) was selected from subjects without diverticular disease of the colon.

Results: Among subjects with diverticular disease of the colon , only one tested positive for celiac disease serologically (Tissue Transglutaminase - TTG IgA and G). In control subjects with dyspepsia, $2.8 \%$ of subjects tested positive for celiac antibodies. There was a robust difference between groups in terms of TTG Ig A seropositivity ( $\mathrm{p}=0.032$, respectively).

Conclusion: The results show an inverse relationship between diverticular disease of the colon and celiac disease. These data support that the presence of celiac antibodies may have a preventive role in the development of colon diverticular disease. The mechanism of the presented finding is still unclear. More research is needed.
\end{abstract}

Key Words: Celiac disease, Diverticul of colon

\begin{abstract}
Özet
Amaç: Çölyak hastalı̆̆1, pozitif HLA haplotipleri DQ2 ve DQ8 olan deneklerde buğdaya aşırı duyarlılığın neden olduğu bir ince bağırsak malabsorpsiyon sendromudur. Kolonun divertiküler hastalığı, daha çok 40 yaş üstü erişkinlerde görülen kolonun sakküler dilatasyonlarıdır. Bu çalışmada, çölyak hastalığı' nın kolonun divertiküler hastalığ 1 için koruyucu olup olmadığını araştırdık.

Gereç ve Yöntem: Ocak-Ekim 2018 arasındaki 7 aylık dönemde 114 (57 kadın; ortalama yaş $58 \pm 4.1$ yıl) kolonun divertiküler hastalığ 1 hastalığ1 tanısı olan hasta çalısmaya alındı. Yaşa uygun kontrol grubu (100 denek; 50 kadın; ortalama yaş 59 \pm 3.4 yil) kolonun divertiküler hastalığ1 olmayan deneklerden seçildi.

Bulgular: Kolonun divertiküler hastalığ1 tanısı olan denekler arasında sadece bir tanesinde serolojik olarak çölyak hastalığ için pozitif tespit edildi (Doku Transglutaminaz - TTG IgA ve G). Dispepsili kontrol deneklerinde, deneklerin $\% 2.8$ 'inde çölyak antikor pozitifliği tespit edildi. TTG Ig A seropozitifliği açısından gruplar arasında güçlü bir fark vardı (sırasıyla $p$ $=0.032$ ).

Sonuç: Sonuçlar, kolonun divertiküler hastalığ1 ve çölyak hastalığ1 arasında ters bir ilişki olduğunu göstermektedir. Bu veriler, çölyak antikorları varlığının kolon divertiküler hastalığ 1 gelișimini önlevici bir role sahip olabileceğini desteklemektedir. Sunulan bulgunun mekanizması hala belirsizdir. Daha fazla araştırmaya ihtiyaç vardır.
\end{abstract}

Anahtar Kelimeler: Çölyak Hastalığı, Kolon divertikülü

\section{Objective}

Celiac disease (CD) is a syndrome of small intestine malabsorption caused by hypersensitivity to gluten in certain foods. It is an immune-related disease with chronic inflammation in the mucosa and submucosa of the small intestine where there is gluten sensitivity in the gastrointestinal system.
These people are often HLA DQ2 and DQ8 positive. Immunological response begins with CD4 + gluten sensitive T cells activating a Th1 / Th0 type inflammatory response. It causes a chronic inflammatory reaction in the small intestine. Absorption surface loss in the small intestine results in decreased digestive enzymes, impaired absorption of fat, soluble vitamins, iron, B12 and folate. A wide range of clinical symptoms

*Sorumlu Yazar:Mesut Aydin Yuzuncu Yil University, Medical Faculty, Department of Gastroenterology, Van E-mail: gmstaydin@gmail.com Tel: 050668922471 Orcid: Mesut Aydın 0000-0002-7411-1067, Serhat Özer 0000-0001-7552-2776, Yaren Dirik 00000003-4582-8672, Elif Tugba Tuncel 0000-0001-9547-9445, A.Cumhur Dülger: 0000-0002-9328-5185 
are seen, including chronic diarrhea, growth retardation, anemia, arthritis, osteopenia, high liver enzymes and low albumin levels. Endoscopically visible hallmarks of CD are scalloped duodenal folds, fissurations and grooves (Figure-1). Celiac disease is diagnosed using serum celiac autoantibodies in combination with duodenal biopsies. The prevalence of $\mathrm{CD}$ is about $1 \%$ in the world. The prevalence of $\mathrm{CD}$ in Asia is $0.5 \%(1,2)$. If the Turkey is approximately $1 \%$ (3). Moreover, $\mathrm{CD}$ is more common in rural areas of the Near East. $(3,4)$. In addition, there is an important relationship between CD and small intestine adenocarcinoma and EnteropathyAssociated T-cell Lymphoma (EATL) (5). Diverticular disease of the colon (DDC) is one of the major gastrointestinal diseases that cause serious morbidity and mortality. DDC includes a wide clinical spectrum from asymptomatic diverticular disease to peritonitis due to perforated acute diverticulitis (6). The formation mechanism of DDC is not yet clear. There are no data describing the prevalence of $\mathrm{CD}$ in patients with DDC. In this study, we aimed to investigate whether there is a relationship between $\mathrm{CD}$ and DDC.

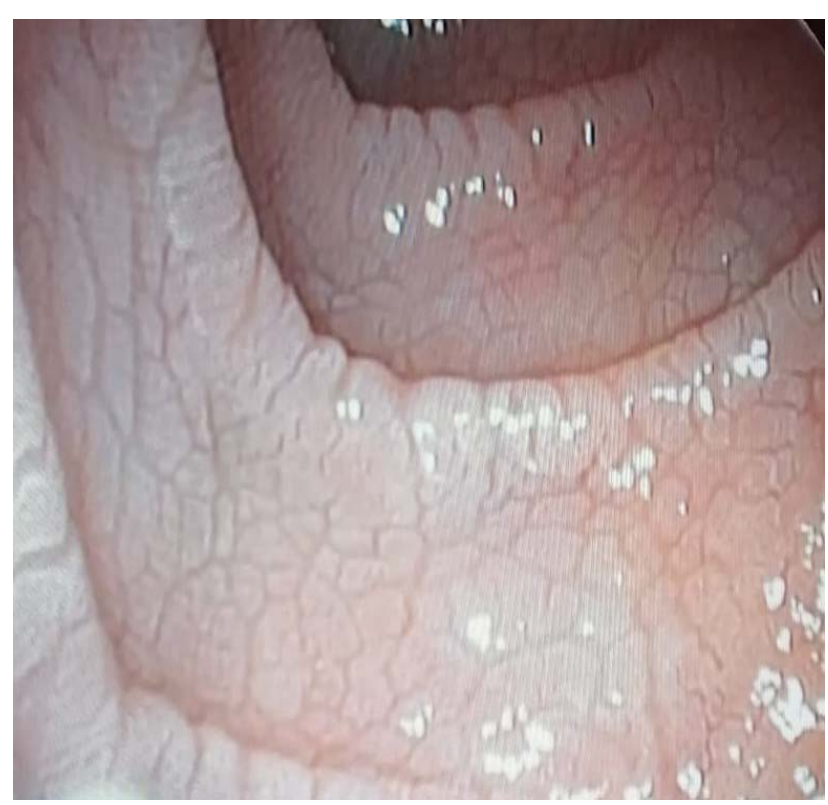

Figure 1. Scalloped duodenal folds, fissurations and grooves

\section{Materyal and Method}

A total of 114 patients (57 women; mean age $58 \pm$ 4.1 years) with DDC between January-October 2018 were included in the study. The diagnosis of DDC was made by colonoscopy and abdominal
CT. Two gastroenterologists specializing in colonoscopy performed the examinations in a blind way. Control group (100 subjects; 50 females; mean age $59 \pm 3.4$ years) was selected from subjects without DDC. Selective $\operatorname{IgA}$ deficiency, colorectal cancer (CRC), perforation, and inflammatory bowel disease (IBD) and those with a previous diagnosis of CD were not included in the study. Data was performed retrospectively. Demographic and laboratory data, colonoscopy reports, tissue transglutaminase antibodies (TTG IgA and $\operatorname{IgG}$ ) results were analyzed Van Yüzüncü Y1l University Ethics Committee approval was received (Etical number:2020/07-24).

Serologic Studies: $\operatorname{IgA}$ and $\operatorname{IgG}$ were measured using human recombinant TTG (AESKULISA, Aesku. Diagnostic, Germany). Aeskulisa TTg-A and TTg-G are solid phase enzyme immunoassays that detect quantitatively and qualitatively $\operatorname{IgA}$ IgG antibodies against neo-epitopes of TTG in human serum. The human recombinant transglutaminase test cross-linked with gliadinespecific peptides shows neo-epitopes of the TTg, which provides significantly increased sensitivity and specificity. The test is used in the diagnosis and monitoring of celiac disease (gluten sensitive enteropathy).

Statistical Analysis: Descriptive statistics were presented as Mean and Standard deviation for the continuous variables, while count and percentages for the categorical variables. Student $t$ test was used to compare groups for continuous variables. $\mathrm{Z}$ test was used for comparison of two proportions. Statistical significance level was considered as 5\% and SPSS (ver: 13) statistical program was used for all statistical computations.

\section{Results}

A total of 114 DDC patients, 57 men (50\%) and 57 women $(50 \%)$, were included in the study. Their mean age was $64 \pm 2.3$ years (48-80 age range). Serology was positive for $\mathrm{CD}$ in only one subject in the study group with DDC (both TTG $\operatorname{IgA}$ and $\operatorname{IgG}$ ). In the control group, $2.8 \%$ of celiac antibodies were positive. There was a significant difference between the groups in terms of TTG $\operatorname{IgA}$ seropositivity $(p=0.032)$. The prevalence of $\mathrm{CD}$ was found to be significantly lower in patients with DDC compared to the control group ( $p$ $=0.024)$. The mean creatinine level of the patients with DDC was higher than the control group (1.0 \pm 0.63 versus $0.74 \pm 1.19 ; \mathrm{p}=0.026)$.We also showed that those with positive TTG IgA had significantly higher glucose and AST levels than those without TTG IgA. (115 \pm 36.6 versus 97 
$\pm 17.4 ; \mathrm{p}=0.032$ and $40 \pm 34.4$ versus $21 \pm 13$; $\mathrm{P}=0.008)$.

\section{Discussion}

These data represent the first analysis of the prevalence of $\mathrm{CD}$ in patients with DDC. In patients with positive celiac antibodies, the possibility of DDC was lower. The incidence of gastrointestinal diseases is high in CD. Recent guidelines recommend a screening program for malignancy in these patients (7). However, there has not been a study showing the relationship between DDC and CD to date. Therefore, it is the first study evaluating the presence and rate of $\mathrm{CD}$ in patients with DDC. CD is the gluten sensitivity of the proximal small intestine. Genetic and environmental factors are important in etiology. There is a close relationship between HLA haplotypes (HLA-DQ2 and DQ8) and CD. Diarrhea was a common clinical finding in the past. (8). The prevalence of gluten sensitive enteropathy is approximately $1 \%$ in the world, depending on the size of the population and the procedure of laboratory methods. However, 90\% of patients can be missed because they go unnoticed (9). On the other hand, the prevalence of DDC is increasing due to the long life expectancy. Abdominal computed tomography (CT) and colonoscopy are important examinations in the diagnosis of DDC. Increasing age, low fiber and high meat diet, increased mucosal inflammation and enteric neuroinflammation play a role in the pathogenesis of DDC (10). According to reports, the overall prevalence of DDC in the USA is $60 \%$ (11), while the prevalence of colon diverticulum in Japanese individuals is $23.9 \%$ (12). With these findings, the prevalence of DDC was found to be lower in the Japanese population than in western populations. Furthermore, authors also showed that the prevalence of Celiac disease was considered very low with the lowest genetic disposition in many Asian populations. This low rate has been caused by low wheat consumption for people living in Japan where rice is the mainstay of the daily diet (13). We hypothesized that lower incidence of both CD and DDC in Japan might be related to low wheat consumption per capita. At the gluten perspective, a causal link between DDC and wheat consumption could lead to low rate of $\mathrm{CD}$ in patients with DDC. Interestingly, an Italian study involving patients with uncomplicated diverticular disease revealed that colonic mucosa of the subjects had no evidence of inflammation in terms of IL2, IL4, IL5, IL8, IL10, IL12p70, IL13, IFN gamma, TNF- alpha and TGF-beta (14). In addition, we think that the inverse correlation seen between DDC and $\mathrm{CD}$ may be related to the lack of mucosal inflammation in the small intestine as well as in the large intestine. On the other hand, diarrhea is the one of the most common symptom of CD. However, diverticulosis has known to be caused by constipation (15). In the study of Zuleyha et al., the frequency of colon diverticulum was found to be $6 \%(16)$. In order to explain the inverse correlation between DDC and CD, we secondly postulate that diarrhea leads less DDC by preventing constipation.There were several limitations of the study. First, due to retrospective nature of the study we did not perform upper gastrointestinal system endoscopy to obtain duodenal biopsy samples. Second, study size was not large enough to generalize the study findings to entire population. Lastly, we did not obtain the dietary behavior of the subjects in assessing the effect of wheat consumption on both diseases. On the other hand, this is the first study in English literature to reveal the inverse correlation between $\mathrm{CD}$ and DDC. In conclusion; dietary and mucosal factors leading to increased probability of DDC may also have a preventive role for CD.

Conflict of Interests: The authors have no conflict of interest.

\section{References}

1. Green P-H-R-Cellier C. N Engl J Med 2007; 357:1731-1743.

2. Singh P, Arora S, Singh A, Strand TA, Makharia GK. Prevalence of celiac disease in Asia: A systematic review and meta-analysis. J Gastroenterol Hepatol. 2016 ;31(6):10951101.

3. Gursoy S, Guven K, Simsek T, Yurci A, Torun E, Koc N, Patiroglu TE, Ozbakir O, Yucesoy M. The prevalence of unrecognized adult celiac disease in Central Anatolia. J Clin Gastroenterol 2005; 39: 508-511.

4. Cummins AG, Roberts-Thomson IC. Prevalence of celiac disease in the AsiaPacific region. J Gastroenterol Hepatol 2009; 24(8):1347-1351.

5. Fasano A, Catassi C. Clinical practice. Celiac disease. N Engl J Med 2012; 367(25):24192426.

6. Jacobs DO. Clinical practice. Diverticulitis. N Engl J Med 2007; 357(20): 2057-2066.

7. Rubio-Tapia A, Hill ID, Kelly CP, Calderwood AH, Murray JA; American College of Gastroenterology. ACG clinical guidelines: diagnosis and management of 
celiac disease. Am J Gastroenterol 2013; 108(5):656-677.

8. Tovoli F, Masi C, Guidetti E, Negrini G, Paterini P, Bolondi L. Clinical and diagnostic aspects of gluten related disorders. World J Clin Cases 2015; 3 (3):275-284.

9. Lebwohl B, Sanders DS, Green PHR. Coeliac disease. Lancet 2018; 391(10115):7081.

10. Pfützer RH, Kruis W. Management of diverticular disease.Nat Rev Gastroenterol Hepatol 2015; 12(11):629-638.

11. Peery AF, Keku TO, Martin CF, Eluri S, Runge T, Galanko JA, et al. Distribution and characteristics of colonic diverticula in a United States screening population. Clin Gastroenterol Hepatol 2016; 14(7): 980-985.

12. Yamamichi $N$, Shimamoto $T$, Takahashi $Y$, Sakaguchi Y, Kakimoto H, Matsuda R, et al. Trend and risk factors of diverticulosis in Japan: age, gender, and lifestyle/metabolicrelated factors may cooperatively affect on the colorectal diverticula formation. PLoS One 2015; 10(4):e0123688.

13. Makharia GK, Catassi C. Celiac Disease in Asia. Gastroenterol Clin North Am 2019; 48(1):101-113.

14. 1li L, Roncoroni L, Bardella MT, Terrani C, Bonura A, Ciulla M, Marconi S, Piodi L. Absence of mucosal inflammation in uncomplicated diverticular disease. Dig Dis Sci 2011; 56(7):2098-2103.

15. Painter NS, Burkitt DP. Diverticular disease of the colon: a deficiency disease of Western civilization. Br Med J. 1971; 2 (5759):450454

16. Çetïnkaya. Z, Sezikli. M, Güzelbulut. F, Altınöz. M, Değirmenci. A, Gökden. Y, ve ark. Demir eksikliği anemili hastalarda gastrointestinal endoskopik inceleme sonuçları. Dicle Tip Dergisi 2011;38 (2): 155-159 . 